\title{
Survivin co-ordinates formation of follicular T-cells acting in synergy with Bcl-6
}

\author{
Karin M. E. Andersson ${ }^{1, *}$, Mikael Brisslert ${ }^{1, *}$, Nicola Filluelo Cavallini ${ }^{1}$, Mattias N. D. \\ Svensson $^{1,4}$, Amanda Welin ${ }^{1}$, Malin C. Erlandsson ${ }^{1}$, Michael J. Ciesielski ${ }^{2}$, Gergely \\ Katona $^{3}$, Maria I. Bokarewa ${ }^{1}$ \\ ${ }^{1}$ Department of Rheumatology and Inflammation Research, The Sahlgrenska Academy at University of Gothenburg, \\ Gothenburg, Sweden \\ ${ }^{2}$ Department of Neurosurgery, Roswell Park Cancer Institute and State University of New York School of Medicine and \\ Biomedical Sciences, Buffalo, NY, USA \\ ${ }^{3}$ Department of Chemistry and Molecular Biology, University of Gothenburg, Gothenburg, Sweden \\ ${ }^{4}$ Division of Cellular Biology, La Jolla Institute for Allergy \& Immunology, La Jolla, CA, USA \\ *These authors have contributed equally to this work
}

Correspondence to:

Maria I. Bokarewa, e-mail: maria.bokarewa@rheuma.gu.se

Keywords: Immune response, Immunity, Immunology and Microbiology Section, survivin, Bcl6, T-cells, autoimmunity, arthritis

Received: May 19, $2015 \quad$ Accepted: July 30, $2015 \quad$ Published: August 12, 2015

\section{ABSTRACT}

Follicular $T$ helper ( $T f h$ ) cells are recognized by the expression of CXCR5 and the transcriptional regulator $\mathrm{Bcl}-6$. Tfh cells control B cell maturation and antibody production, and if deregulated, may lead to autoimmunity. Here, we study the role of the proto-oncogene survivin in the formation of Tfh cells. We show that blood Tfh cells of patients with the autoimmune condition rheumatoid arthritis, have intracellular expression of survivin. Survivin was co-localized with Bcl-6 in the nuclei of CXCR5+CD4 lymphocytes and was immunoprecipitated with the Bcl-6 responsive element of the target genes. Inhibition of survivin in arthritic mice led to the reduction of CXCR5 ${ }^{+}$ Tfh cells and to low production of autoantibodies. Exposure to survivin activated STAT3 and induced enrichment of PD-1+Bcl-6+ subset within Tfh cells. Collectively, our study demonstrates that survivin belongs to the Tfh cell phenotype and ensures their optimal function by regulating transcriptional activity of Bcl-6.

\section{INTRODUCTION}

Follicular $\mathrm{T}$ helper cells (Tfh) is a subtype of memory $\mathrm{T}$ cells residing in secondary lymphoid structures, germinal centers (GC), and regulating B cell maturation and antibody production. Tfh cells exhibit specific phenotype by up-regulating chemokine receptor CXCR5 compulsory for their follicular localization, and surface molecules ICOS, PD-1, and SLAM, essential for interaction with B-cells $[1,2]$. Generation and function of Tfh cells is a topic of special interest since their insufficiency is associated with immunodeficiency, while over-activation predispose to autoimmunity. The inflammatory milieu promotes the Tfh phenotype contributing with cytokines to activate the signal transducer and activator of transcription 3 (STAT3) $[3,4]$. In particular, the cytokines IL-6, IL-27 and IL-21 have key roles at different stages of Tfh development and mediate STAT-3 dependent production of the transcriptional factor B-cell lymphoma 6 (Bcl-6) [5] $[6,7]$. The expression of Bcl-6 in Tfh is prerequisite of $\mathrm{GC}$ formation and of extra follicular antibody responses [8]. In human setting, Tfh cell phenotype may also be induced through an alternative activation of IL-12 receptor and tyrosine kinase Tyk [9].

Rheumatoid arthritis (RA) is a chronic joint inflammation [10, 11]. The formation of ectopic $\mathrm{GC}$ is morphological characteristic feature of the inflamed rheumatoid synovium [12]. Synovial GCs are currently viewed as a place of affinity maturation and clonal expansion of $\mathrm{B}$ cells producing arthritis specific autoantibodies [13, 14]. The production of autoantibodies, which recognize the Fc-portion of human IgG, called rheumatoid factor (RF), and citrullinated protein epitopes (ACPA), is widely used in diagnostic of RA and also to identify the patients 
at risk to develop aggressive and therapy resistant RA [15-18]. It has recently been demonstrated that human circulating CXCR5+ memory T-cells are counterparts of the Tfh cells residing in GC and support differentiation of naïve $B$ cells into plasmablasts and antibody producing plasma cells in healthy subjects and in autoimmunity [19-21]. The excess of Tfh cells in peripheral blood is reported in myasthenia gravis, thyroiditis, systemic lupus erythematosus, Sjögren's syndrome and juvenile dermatomyositis [2, 22]. Most of the reports show a correlation between Tfh cells and humoral autoimmunity in these patients, where the increased number of circulating Tfh is associated with disease activity, high levels of IL-21 and the presence of ACPA and RF [23-26]. Functionally active Tfh cells are identified in blood circulation during RA remission [27, 28] Notably, RA patients are early recognized by IL-6 dependent activation of STAT3 [29-32], the major driving mechanism of Tfh development. However, the origin of $\mathrm{Tfh}$ and molecular forces supporting their persistence in RA remains unrevealed.

This study addresses the role of the oncoprotein survivin in the formation of Tfh in RA. Following the initial description of survivin [33], the studies on survivin are concentrated on its anti-apoptotic and cell cycle regulatory properties in malignancies [34]. Later on, survivin was found important for the formation of functional TCR in the developing thymocytes $[35,36]$ and for the Flt3-dependent maturation of dendritic cells $[37,38]$. In the immune competent cells, survivin production is required for the antigen presentation and for the formation of memory immune responses [39]. These processes are known as a hallmark of aberrant immunity in RA. In the established RA, high serum levels of survivin are frequently measured in patients producing RF and/or ACPA [40, 41]. The combination of survivin and autoantibodies recognizes RA patients with persistent disease activity and progressive joint damage $[42,43]$. In the rheumatoid synovia, survivin was found in the areas enriched with macrophages and memory T cells [44-46]. Inhibiting survivin in arthritic mice restored the control over T-cell proliferation, and reduced arthritis [47]. At early pre-clinical stage of RA, serum levels of survivin correlated with the cytokines predisposing and assuring formation of Th1 and Th17 cells regulating the initial stages of RA pathology [48].

In this study we demonstrate that survivin belongs to the Tfh phenotype. It is expressed in the majority of circulating CXCR5+ memory $\mathrm{T}$ cells of RA patients and in arthritic mice. Changes in survivin transcription modulate formation and function of Tfh by regulating transcriptional activity of Bcl-6. This reduces CXCR5 expression and autoantibody production. Exposure to extracellular survivin restrains Tfh cells inducing PD- $1^{+}$ Bcl- $6^{+}$phenotype of existing $\mathrm{CXCR}^{+}$survivin $^{+} \mathrm{T}$ cells.

\section{RESULTS}

\section{Survivin and Bcl-6 are present in the peripheral blood follicular $T$ helper cells of patients with rheumatoid arthritis}

Intracellular expression of survivin was analyzed by flow cytometry in the PBMC of RA patients $(n=21)$ and healthy subjects $(n=10)$ and revealed an enrichment of survivin ${ }^{+}$cells within the memory $\mathrm{CD}^{2} 5 \mathrm{RA}^{-} \mathrm{CD}^{+} \mathrm{T}$ cells compared to naïve $\left(\mathrm{CD}_{4} 5 \mathrm{RA}^{+}\right)$cells in RA patients. In RA patients, the difference was seen both with respect to the propensity (46.0\% vs $26.6 \%, p=0.0012)$ and to the intensity (MFI: 3654 vs 2256, $p=0.007$ ) of survivin expression (Figure 1A, 1B). In healthy controls, survivin+ cells were more prevalent in the naïve compared to memory CD4+T cells $(33.4 \%$ vs. $56.4 \%, p=0.041)$ and had no difference in the intensity of survivin expression (MFI, median: 3666 vs 3633).

The survivin ${ }^{+} \mathrm{CD}^{+}$cells expressed chemokine receptor CXCR5 essential for the GC localization of Tfh cells. Actually, CXCR5 was expressed almost exclusively within survivin ${ }^{+}$population of $\mathrm{CD}^{+} \mathrm{T}$ cells (Figure 1C). Functional Tfh cells require expression of master transcription regulator Bcl-6 [22, 49]. Bcl-6 was identified in $2.5-38 \%$ of the survivin ${ }^{+}$memory $\mathrm{CD}^{+}$cells, which was more prevalent compared to survivin ${ }^{-}$memory $\mathrm{CD}^{+}$cells (Table 1, Figure 1D). Presence of Bcl-6 was associated with higher survivin expression within the survivin ${ }^{+} \mathrm{CXCR}^{+}$cells (Figure $1 \mathrm{E}$ ).

To verify expression of survivin during $\mathrm{Tfh}$ cell formation, human PBMC were forced into Tfh phenotype by CD3 activation combined with IL-12 or IL-21. Adoption of Tfh phenotype was evaluated by expression of CXCR5 receptor and the intracellular production of IL-21 within the PD- $1^{+}$survivin $^{+}$CD4 cells. Cell stimulation with $\alpha \mathrm{CD} 3+$ IL-12 and $\alpha \mathrm{CD} 3+$ IL-21 resulted in up-regulation of CXCR5 on the survivin $^{+}$CD4 cells, which was more prominent with the $\alpha \mathrm{CD} 3+\mathrm{IL}-12$ stimulation (Figure $1 \mathrm{~F}$ ). The $\alpha \mathrm{CD} 3+$ IL-12 stimulation increased IL-21 production on $\mathrm{PD}-1^{+} \mathrm{CXCR}^{+}$survivin $^{+}$cells compared to $\alpha \mathrm{CD} 3$ stimulated cell cultures (Figure $1 \mathrm{G}$ ). Stimulation with $\alpha \mathrm{CD} 3+\mathrm{IL}-12$ enlarged the $\mathrm{CXCR}^{+} \mathrm{PD}-1^{+}$survivin $^{-}$ population of CD4 cells (Figure 1F). This population showed no increase in the IL-21 production (Figure 1G).

\section{Survivin and Bcl-6 localize within the nuclei of human CXCR5+ T cells}

The co-expression of survivin and CXCR5/Bcl-6 within Tfh cells was further confirmed by imaging flow cytometry analysis. Freshly isolated human PBMC gated on $\mathrm{CXCR}^{+}$cells comprised a subset that co-expressed both survivin and Bcl-6 (Figure 2A), confirming the above 

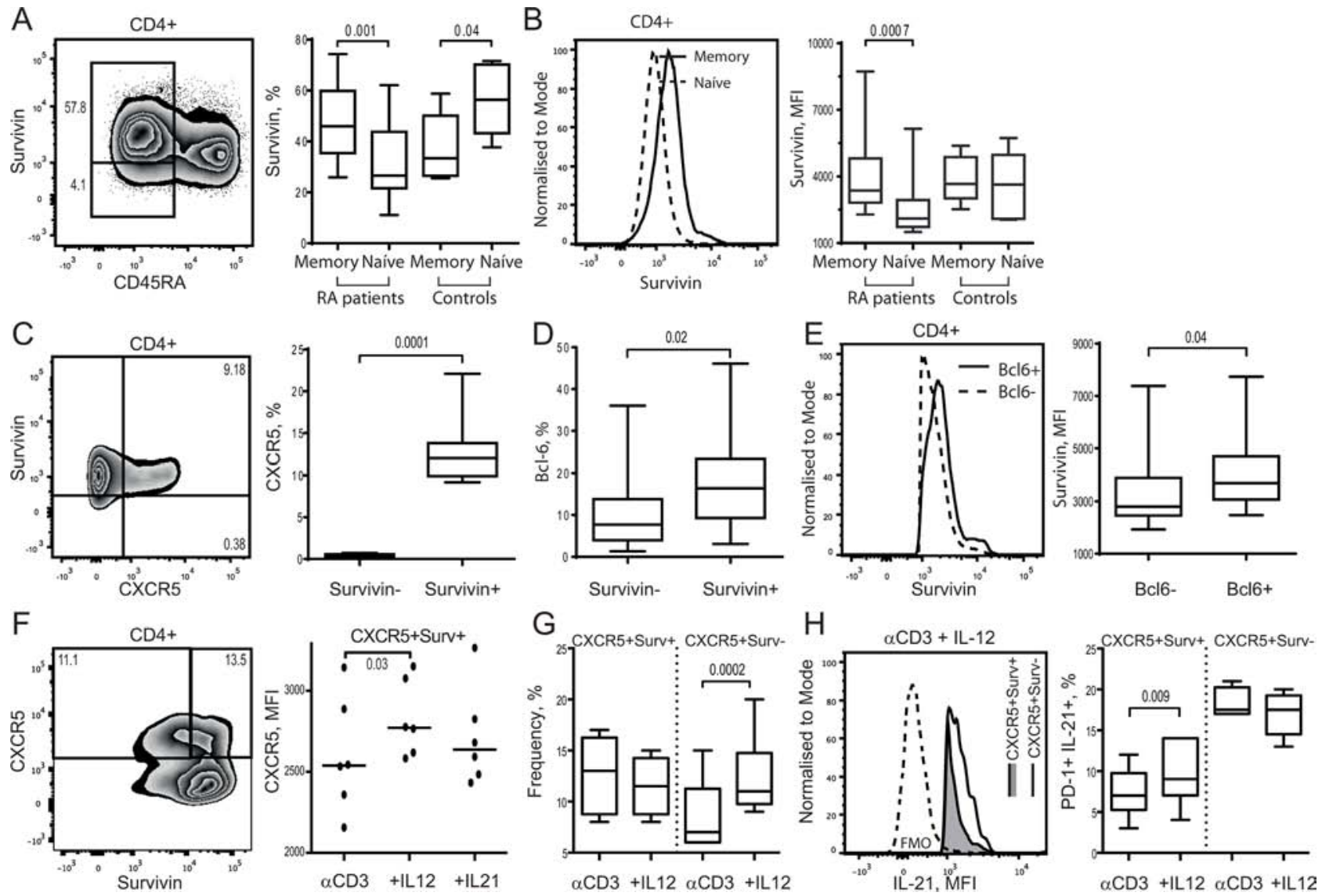

Figure 1: Survivin expression is an essential feature of human $\mathbf{C X C R 5}^{+} \mathbf{T f h}$ cell phenotype. Intracellular expression of survivin was investigated in memory $\left(\mathrm{CD} 45 \mathrm{RA}^{-}\right)$or naïve $\left(\mathrm{CD} 45 \mathrm{RA}^{+}\right) \mathrm{CD} 4^{+} \mathrm{T}$ cells of RA patients $(n=21)$ and healthy controls $(n=10)$ using flow cytometry. Cells are gated on $\mathrm{CD}^{+}$lymphocytes. Box plots show the frequency of survivin ${ }^{+}$cells A. and the mean fluorescence intensity (MFI) of survivin B. Expression of CXCR5 C. within survivin ${ }^{+}$and survivin ${ }^{-}$CD4 ${ }^{+}$cells, and Bcl-6 D. within survivin ${ }^{+}$and survivin $^{-}$memory $\left(\mathrm{CD} 45 \mathrm{RA}^{-}\right) \mathrm{CD}^{+}$cells of RA patients. The intensity of survivin expression E. within Bcl- $6^{+}$and Bcl-6 $6^{-}$survivin ${ }^{+}$ $\mathrm{CXCR}^{+} \mathrm{CD} 4$ cells. The Mann-Whitney $U$-test was used to compare differences between groups. PBMCs of healthy subjects $\left(1 \times 10^{6} / \mathrm{ml}\right.$, $n=6)$ were cultured with anti-CD3 $(0.25 \mu \mathrm{g} / \mathrm{ml})$ alone or in combination with IL-12 $(20 \mathrm{ng} / \mathrm{ml})$ or IL-21 $(50 \mathrm{ng} / \mathrm{ml})$. On day 5 , the formation of Tfh cells was recognized by expression of CXCR5 and intracellular production of IL-21. Cells were gated on viable CD4 $4^{+}$lymphocytes. Intensity of CXCR5 expression on survivin + CD4 cells is shown $\mathbf{F}$. The frequency of CXCR5 ${ }^{+}$cells within survivin ${ }^{+}$and survivin ${ }^{-}$CD4 subsets stimulated with $\alpha \mathrm{CD} 3+\mathrm{IL}-12$ G. Intracellular production of IL-21 within the CXCR5 ${ }^{+}$survivin $^{+}$and $\mathrm{CXCR}^{+}$survivin $^{-}$CD4 cells $^{-1}$ stimulated with $\alpha \mathrm{CD} 3+\mathrm{IL}-12$ is shown by histogram $\mathbf{H}$. Frequency of PD- $1^{+}$IL-2 $1^{+}$cells is shown by box plots I. The Wilcoxon matchedpairs signed rank test to compare differences. Boxes and lines represent IQR and median, respectively, and error lines indicate min and max values.

described flow cytometry data. The images reveal CXCR5 position at the periphery of the cells, forming uneven clusters of higher intensity along the plasma membrane. Under the non-stimulated conditions, the staining for survivin was predominantly identified in the cytoplasma, often in the vicinity or within the CXCR5 clusters attached to the cell membrane. Bcl-6 staining was mainly localized to the nucleus of CXCR $5^{+}$cells. In the non-stimulated cells, only a few of the survivin pixels had nuclear location. In the isolated and activated $\mathrm{CD}^{+} \mathrm{T}$ cells, the nuclear co-localization of survivin and Bcl-6 was clearly observed (Figure 2B). Survivin is seen enriched in the perinuclear area and its partial translocation into the nucleus occurred, which corresponded to co-localization of the survivin and DAPI staining. The stimulated $\mathrm{T}$ cells had intense and more condensed nuclear staining for Bcl-6, where survivin and Bcl-6 were co-localized to the same pixels.

\section{Survivin binds to the Bcl-6 responsive elements of Blimp-1 and p53 genes}

Functional and biochemical evidence for a direct role for Bcl-6 in transcriptional repression are most studied on the genes encoding Blimp-1 (Prdml) [50, 51] and the cell cycle regulator p53 $[52,53]$. Therefore, we examined whether survivin bound to the Bcl-6-responsive elements (BRE) of these genes. To detect DNA-bound survivin within BRE of the Prdml gene we performed 
Table 1: Clinical characteristics of patients with rheumatoid arthritis

\begin{tabular}{|c|c|}
\hline$n=21$ & Mean \pm SD [range] \\
\hline Survivin $^{+} \mathrm{Bcl}^{-6^{+}}$ & $13.9 \pm 10.1 \%$ \\
\hline$\left(\mathrm{CD}^{2} 5 \mathrm{RA}^{-} \mathrm{CD} 4^{+}\right)$ & $4040 \pm 1393, \mathrm{MFI}^{\mathrm{a}}$ \\
\hline Gender, F/M & $16 / 5$ \\
\hline Age, years & $64 \pm 9.6$ \\
\hline Disease duration, years & $20.4 \pm 11.6$ \\
\hline $\mathrm{RF}^{\mathrm{b}} / \mathrm{ACPA}^{\mathrm{c}}$ positive, $n$ & 20 \\
\hline DAS28 ${ }^{d}$ & $2.4 \pm 0.89[1.0-3.86]$ \\
\hline $\mathrm{MTX}^{\mathrm{e}}, \mathrm{mg} /$ week & $15.8 \pm 5.0$ \\
\hline Infliximab, $\mathrm{g}$ & $9.6 \pm 4.2[2.6-16.6]$ \\
\hline
\end{tabular}

${ }^{a}$ Mean fluorescence intensity,

${ }^{b}$ Rheumatoid factor,

'Anti citrullinated protein antibodies,

${ }^{\mathrm{d} D i s e a s e}$ Activity Score in 28 Joints,

${ }^{\mathrm{e}}$ Methotrexate

a chromatin immunoprecipitation (ChIP) analysis of human LPS/Concanavalin A-stimulated PBMC. The immunoprecipitation with anti-survivin antibodies showed that the amplified BRE was 14-15-fold enriched with survivin in 3 independent experiments (Figure 2C, 2D). The same BRE region showed the 10-30-folds enrichment when immunoprecipitated with anti-Bcl-6 antibodies (Figure 2C, 2D). No enrichment of the BRE region was observed with the isotype-matched control antibodies.

ChIP assays of the promoter region of the $p 53$ gene, containing BRE, could identify the enrichment of survivin and of Bcl-6 within this region of human LPS/ Concanavalin A-stimulated PBMC (Figure 2C, 2D). These results showed that survivin was present on the BRE within the $p 53$ and $\operatorname{Prdm} 1$ genes in amounts comparable with Bcl-6 itself; therefore, survivin may be required for Bcl-6-dependent repression of these genes.

\section{A structural model of the survivin-Bcl-6 interaction}

Given the amount of evidence supporting the co-localization of survivin with Bcl-6, we next hypothesized a direct interaction between these proteins and how this putative complex may form. Bcl-6 contains a versatile protein-protein interaction motif known as BTB domain, a primary interaction site with its co-repressors $[54,55]$, at the N-terminus and a typical array of six $\mathrm{C} 2 \mathrm{H} 2$ zinc-finger domains connected by an undefined proline-rich region. We uploaded the crystal structure of the unbound human Bcl-6 BTB domain (PDB code 1R28) [55] and the survivin dimer (PDB code 1e31) [56] to the Cluspro2 [57] protein-protein docking server, which excelled when entered into the CAPRI $[58,59]$ docking prediction competition. Both the "standard" and "antibody" modes were tested, but the most plausible models were derived using the "antibody" mode. The best four clusters contained similar complexes presented in Figure $2 \mathrm{E}$ and $2 \mathrm{~F}$. In these models, the survivin BIR domain interacts with Bcl-6 through a shallow cleft on the Bcl-6 BTB domain. The C-terminus of survivin binds tightly to the side of the Bcl-6 BTB domain. The helices of the Bcl-6 BTB domain (aa56-62) interact with the C-terminal helix-turn-helix motif of survivin (aa102-125). The predicted model permits the independent interaction of each survivin subunit with a Bcl-6 subunit, potentially forming linear multimers with 2 -fold symmetry.

\section{Inhibition of survivin transcription affects follicular $T$ cells and reduces antibody production in arthritic mice}

We first studied if expression of survivin is a part of Tfh phenotype in mouse spleen and lymph nodes (LN) by flow cytometry. Similar to human PBMC, survivin was expressed in memory CD44 ${ }^{\mathrm{hi}} \mathrm{CD} 4^{+}$cells of $\mathrm{LN}$ and spleen in mice (Figure 3A). These survivin ${ }^{+}$cells were recognized by high expression of Bcl-6. The majority of survivin ${ }^{+} \mathrm{Bcl}-6^{+}$ cells in the LN and spleen resided within the CXCR5 ${ }^{+}$ population (Figure $3 \mathrm{~B}$ ). The survivin ${ }^{+} \mathrm{CXCR} 5^{+} \mathrm{CD} 4$ cells were also recognized by high expression of PD-1 receptor (Figure 3C), indicating that survivin is a characteristic feature of mouse Tfh cells in spleen and LN.

We next examined if survivin is required for formation of Tfh cells in arthritic mice. Inhibition of survivin by shRNA-producing lentiviral constructs (shSurv) induced a profound reduction in the intensity of survivin in $\mathrm{CD}^{+}$cells (Figure 3D) and in the number of survivin ${ }^{+}$cells in the spleen [47]. The decrease of 

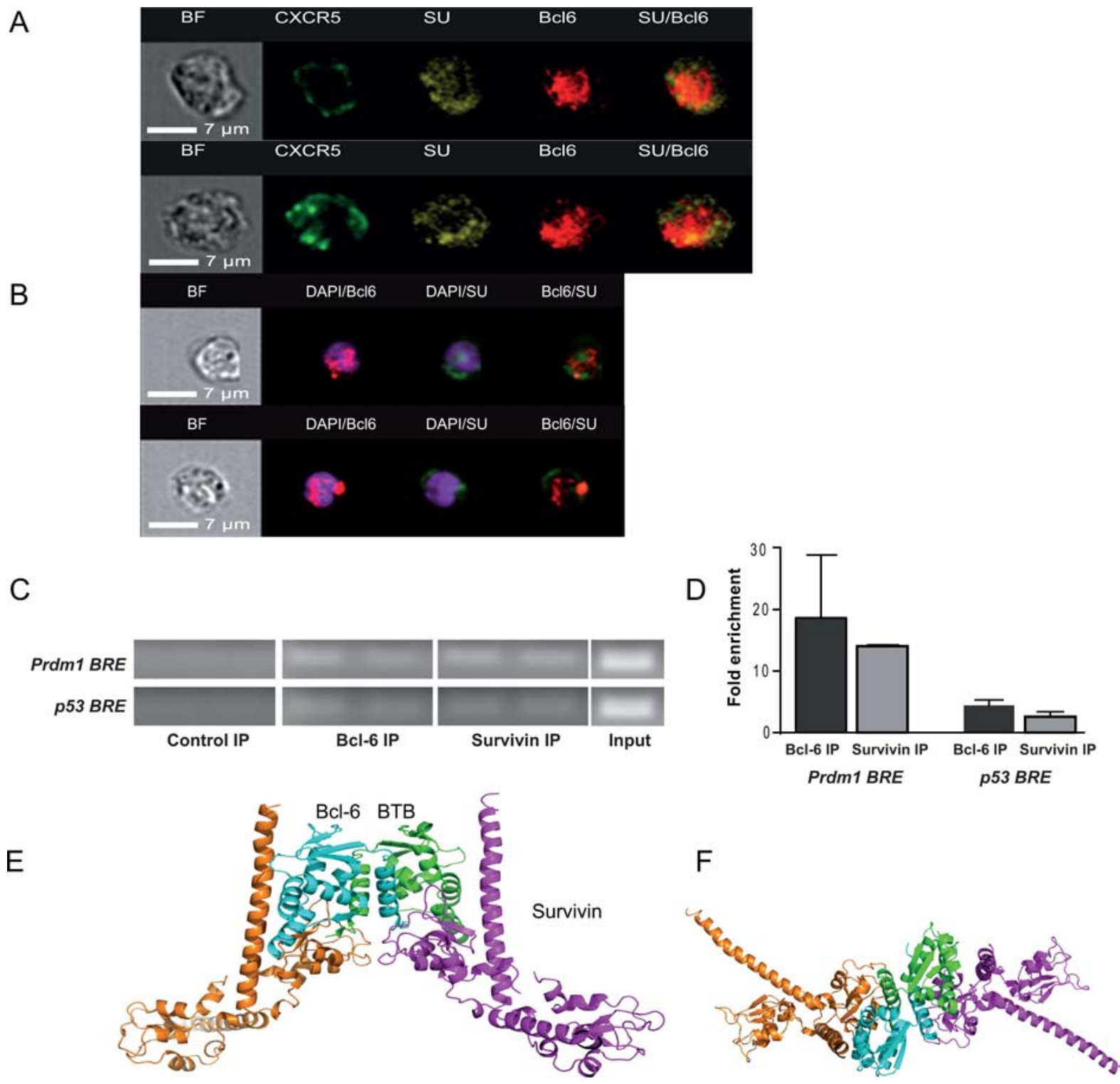

Figure 2: Survivin and Bcl-6 co-localize and interact in human PBMC. Freshly isolated human PBMCs were stained with CXCR5, survivin and Bcl-6, and acquired on an imaging flow cytometer. Cells were gated on CXCR5+ lymphocytes. Localization of CXCR5 (green), survivin (yellow) and Bcl-6 (red) within the same cell could be observed. Co-localization of survivin and Bcl-6 is recognized in the right-side column by yellow staining. Left column shows bright field (BF) analysis of the cells A. CD4 cells isolated from PBMC were stimulated with concanavalin A $(5 \mu \mathrm{g} / \mathrm{ml}, 3 \mathrm{~h})$ and stained for Bcl-6 (red) and survivin (green). Nuclear chromatin was stained with DAPI (purple). The nuclear localization of Bcl-6 and survivin is visualized within the cells B. DNA of human PBMC $(n=4)$, stimulated with LPS/concanavalin A, was immunoprecipitated (IP) with anti-survivin and anti-Bcl-6 antibodies and used in a ChIP assay. Normal IgG was used as a negative control. The IP DNA was then subjected to PCR using primer sets spanning the Bcl-6 response element (BRE) within the $p 53$ promoter or the Blimp-1 gene, $\operatorname{Prdm} 1$ C. The input refers to PCR using $1 \%$ of total chromatin before IP. Quantification of ChIP analysis is presented as fold enrichment to the control IP D. A docking model of the putative survivin-Bcl-6 interaction is proposed and viewed perpendicular to E. and along $\mathbf{F}$. the 2-fold axis of Bcl-6 BTB. The C $\alpha$ ribbons of the survivin dimers are depicted in magenta (representing the 1st cluster) and orange (representing the 4th cluster), while the docking partners (Bcl-6 BTB subunits) are depicted in cyan and green, respectively.

survivin intensity was directly related to the reduction of memory CD44 ${ }^{\text {hi }} \mathrm{CD} 62 \mathrm{~L}^{+} \mathrm{CD} 4$ cells in the shSurv treated mice (Figure 3E). shSurv treatment resulted in a reduced $\mathrm{CXCR}^{+}$subset within the $\mathrm{CD} 44^{\mathrm{hi}} \mathrm{CD} 4^{+}$cells (Figure 3F), which correlated with the decreased survivin intensity (Figure 3G).
Bcl-6 controls the maturation and function of Tfh cells and $\mathrm{GC}$ formation by inducing expression of the homing receptor CXCR5 $[60,61]$. Bcl-6 mRNA in the spleen of shSurv treated mice was directly related to the size of $\mathrm{CXCR}^{+} \mathrm{CD} 44^{\mathrm{hi}}$ population of CD4 T cells (Figure $3 \mathrm{H}$ ). shSurv treated mice formed sufficient $\mathrm{Bcl}-6^{+}$areas within 


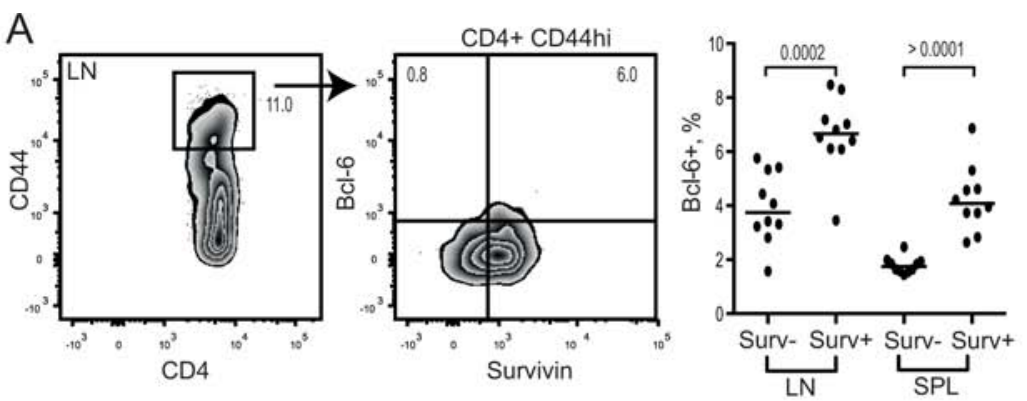

B
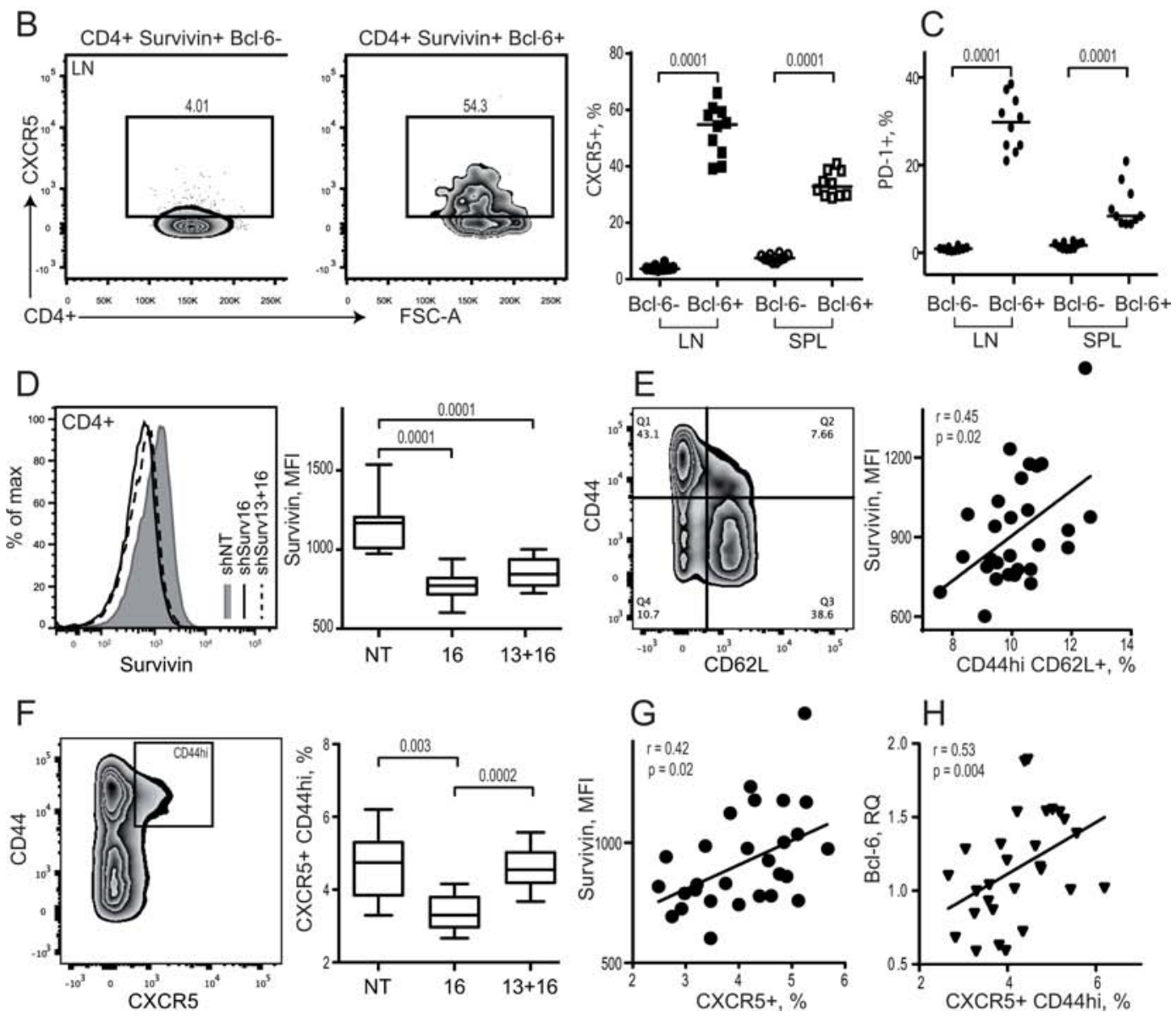

Figure 3: Survivin positive subset of CD44 ${ }^{\text {hi }} \mathrm{CD} 4$ lymphocytes in mouse possess a complete phenotype of Tfh cells. Spleen and lymph nodes from collagen II immunized arthritic (CIA) mice were analyzed for expression of survivin and Bcl-6 using flow cytometry A. Cells were gated on memory $\mathrm{CD} 44^{\text {hi }} \mathrm{CD} 4^{+}$lymphocytes. Expression of CXCR5 B. and PD-1 C. was investigated within Bcl- $6^{+}$survivin $^{+}$ and Bcl-6 survivin $^{+}$cells. Dots represent individual mice and the horizontal line shows median of the group. Survivin translation in CIA mice was inhibited by shRNA-producing constructs provided as a single intra-peritoneal injection ( $\operatorname{shSurv} 16, n=10$, or shSurv13+16, $n=10)$. Control mice were treated with a non-targeting RNA construct ( $\operatorname{shNT}, n=9$ ). Survivin expression in spleen was analyzed by flow cytometry 12 days after the injection. Cells were gated on $\mathrm{CD}^{+}$lymphocytes. Intensity of survivin expression (MFI) within the groups is shown by a representative histogram and summarized in a box plot D. Survivin expression (MFI) on CD4 lymphocytes correlated to the size of CD44 ${ }^{\mathrm{hi}} \mathrm{CD} 62 \mathrm{~L}^{+}$population $\mathbf{E}$. Expression of CXCR5 on CD44h $\mathrm{CD} 4+$ lymphocytes in the groups is shown as box plot $\mathbf{F}$. CXCR5 ${ }^{+}$ population correlates with the intensity of survivin $\mathbf{G}$. and with Bcl-6 mRNA H. Boxes and lines represent IQR and median, respectively, and error lines indicate min and max values. The Mann-Whitney $U$-test was used to compare differences between groups. Correlation analyses were performed using Spearman's test.

the spleen follicles which were comparable to the controls (Figure 4A). The protein content of Bcl-6 in shSurv treated mice was similar to the controls (Figure 4B) despite the increase in Bcl-6 mRNA, and also in IL-21 mRNA promoting Bcl-6 transcription (Figure 4C). The mRNA levels of Bcl-6 correlated positively to the promoters of its transcription (IL-21, IRF4, c-Maf, NFAT1) and to Blimp-1 and Stat5 repressing Bcl-6 transcription (Figure 4D). This 
A

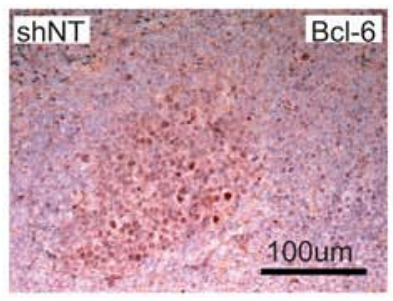

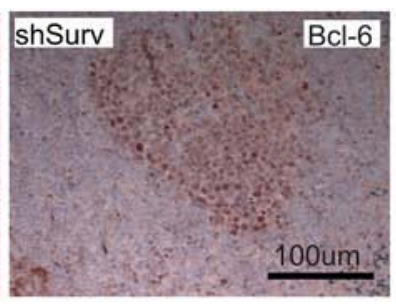

B

C
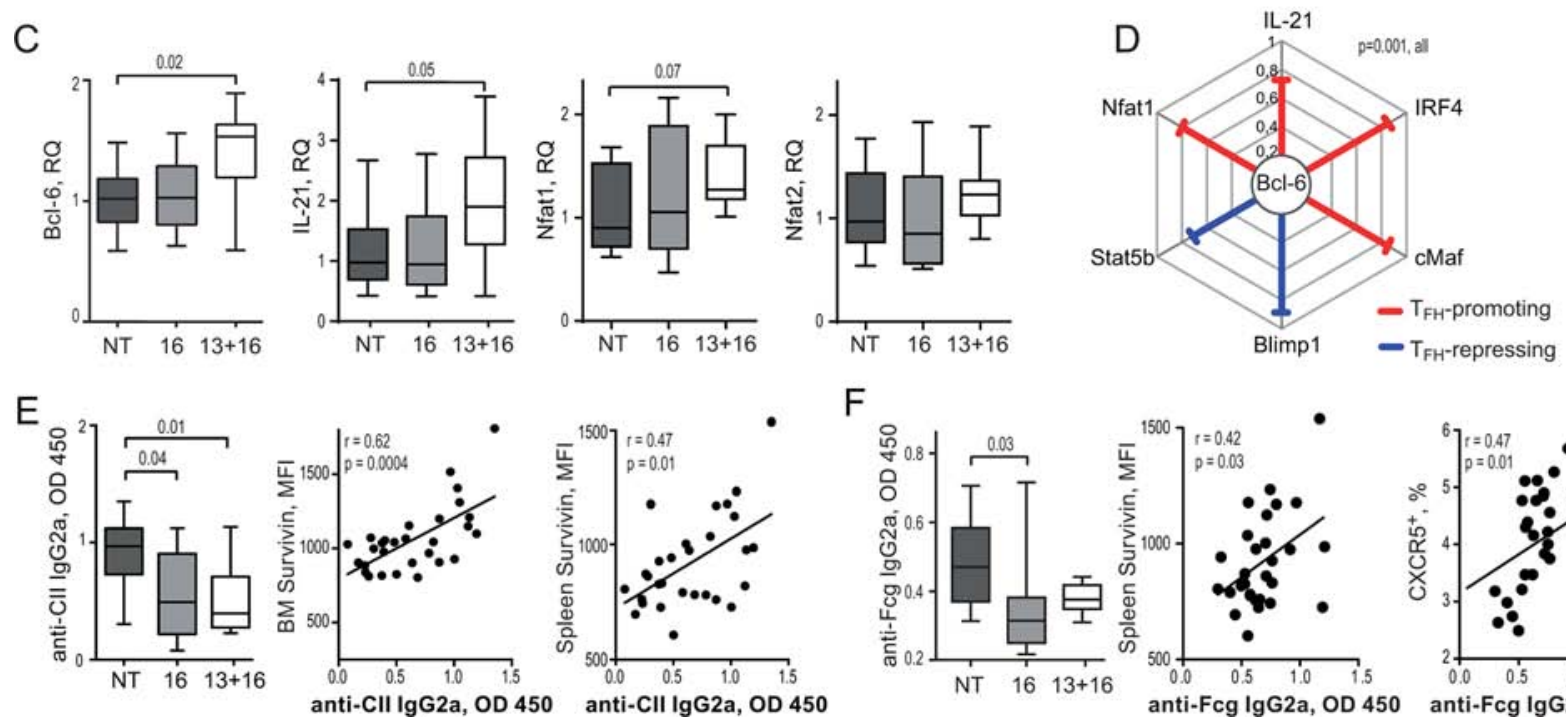

F
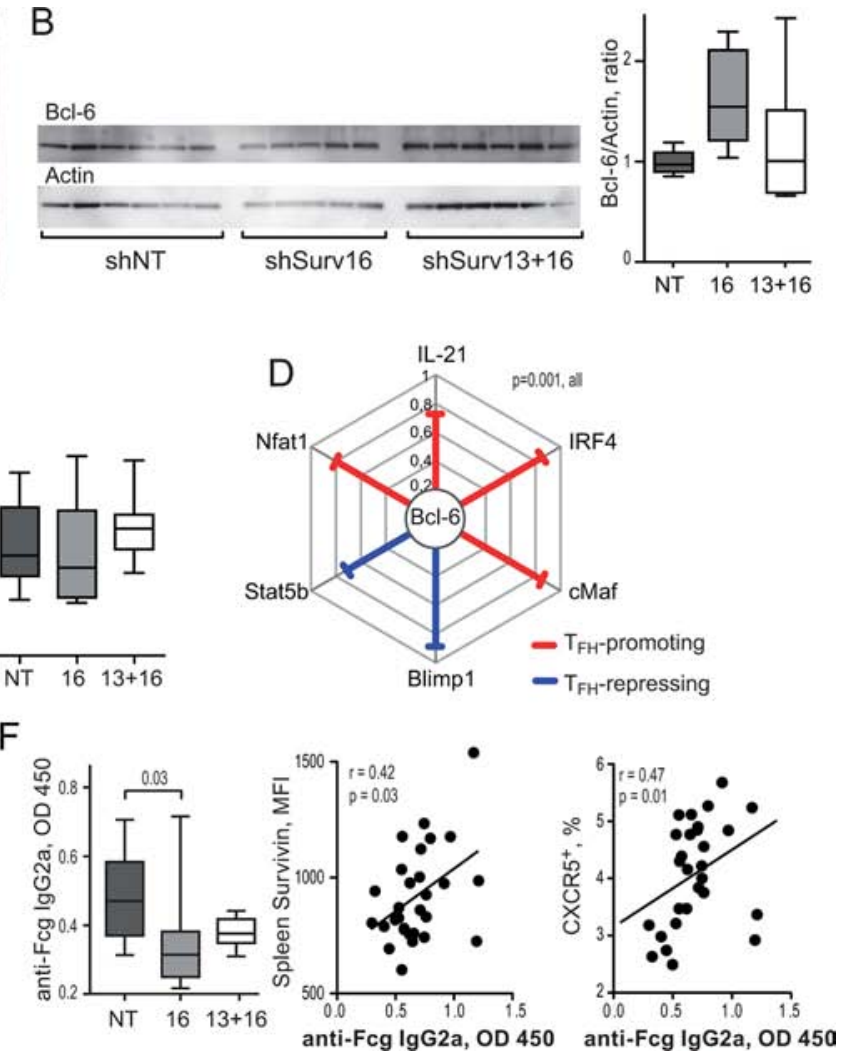

Figure 4: Inhibition of survivin disturbs Bcl-6 dependent mechanisms of antibody production in experimental arthritis. Bcl-6 expression was analyzed in CIA mice treated with the survivin inhibiting (shSurv16 and shSurv13+16) and control (shNT) shRNA constructs, by immunohistological staining for Bcl-6 in spleen A. and by Western blot on bone marrow cells B. Bcl-6 was quantified in ratio to actin of each sample. Statistics for the groups is presented as box plots. Transcription of Bcl-6, IL-21, Nfat1 and Nfat2 in spleen was analyzed by RT-PCR and presented in relative quantity (RQ) to the median of the control group C. Spearman's rank correlation coefficient (rho) between the transcription of Bcl-6 vs. Blimp-1, Stat5b, Nfat1, IL-21, IRF4, and cMaf in spleen of CIA mice are shown D. Anti-collagen II (anti-CII) antibodies E. and anti-Fcgamma (anti-Fcg) antibodies F. in the serum of CIA mice treated with shSurv or shNT were measured by ELISA. Anti-CII antibodies correlated with survivin intensity in bone marrow and in spleen, measured by flow cytometry E. Anti-Fcg antibodies correlated with the intensity of survivin and with size of CXCR5 ${ }^{+}$CD4 population in spleen, measured by flow cytometry F. Boxes and lines represent IQR and median, respectively, and error lines indicate min and max values. The Mann-Whitney $U$-test was used to compare differences between groups. Correlation analyses were performed using Spearman's test.

could reflect the combined input of these mechanisms in regulation of Bcl-6 in the shSurv treated mice. Transcription factor NFAT2 is important for the expression of CXCR5 in Tfh cells acting independently of Bcl-6 [62]. The shSurv treated mice had no significant change in NFAT1 and NFAT2 mRNA levels (Figure 4C).

Consistent with insufficiency in Tfh cells, shSurvtreated mice immunized with $\mathrm{CII}$ had decreased production of antigen-specific and pathogenic anti-CII $\mathrm{IgG}_{2 \mathrm{a}}$ antibodies (Figure 4E) and also of anti-Fc-gamma $\operatorname{IgG}_{2 \mathrm{a}}$ autoantibodies (RF) compared to controls (Figure 4F). Anti-CII $\operatorname{IgG}_{2 \mathrm{a}}$ levels correlated with the reduced survivin ${ }^{+}$ population in the bone marrow $(r=0.62, p=0.0004)$ and spleen $(r=0.47, p=0.01)$ (Figure 4E). The levels of RF showed correlation to the intensity of survivin expression in spleen cells and with the reduced size of $\mathrm{CXCR}^{+} \mathrm{CD} 4^{+}$ subset (Figure 4F).

\section{Immunization with survivin-derived peptides restrained $T f$ population and enlarged autoantibody production}

Since high serum levels of survivin are prevalent in RA patients [40, 63], we ask if exposure to survivin peptides by immunization increases Tfh subset in mice. Arthritis prone DBA/1 mice were immunized with survivin-derived peptide and developed high levels of anti-survivin antibodies (Figure 5A) indicating a sufficient immunization response. Survivin-immunized mice had also increased production of anti-Fc-gamma $\mathrm{IgG}_{1}$ autoantibodies and serum survivin (Figure 5A) compared to OVA-immunized control mice, which resembled the phenotype of RA patients.

The total survivin ${ }^{+}$population within the mature $\mathrm{CD} 44^{\text {hi }}{ }^{\mathrm{CD}} 4^{+}$cells (Figure 5B) and $\mathrm{CXCR}^{+} \mathrm{CD} 4^{+}$ 


\section{A}
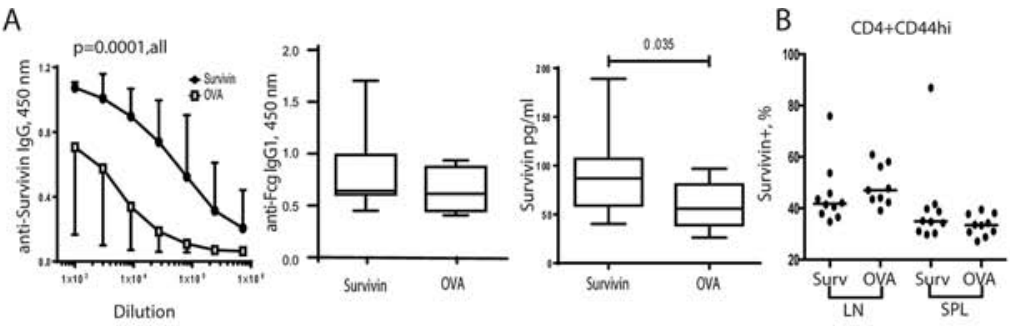

C CD4+surv+CXCR5+

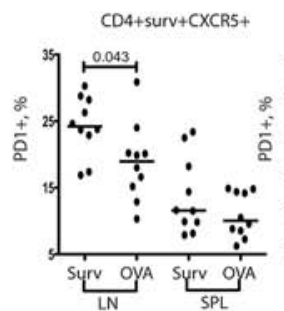

D $\mathrm{CD} 4+$

E CD4+surv+CXCR5+

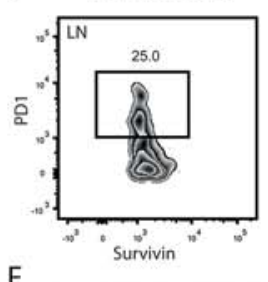

LN SPL
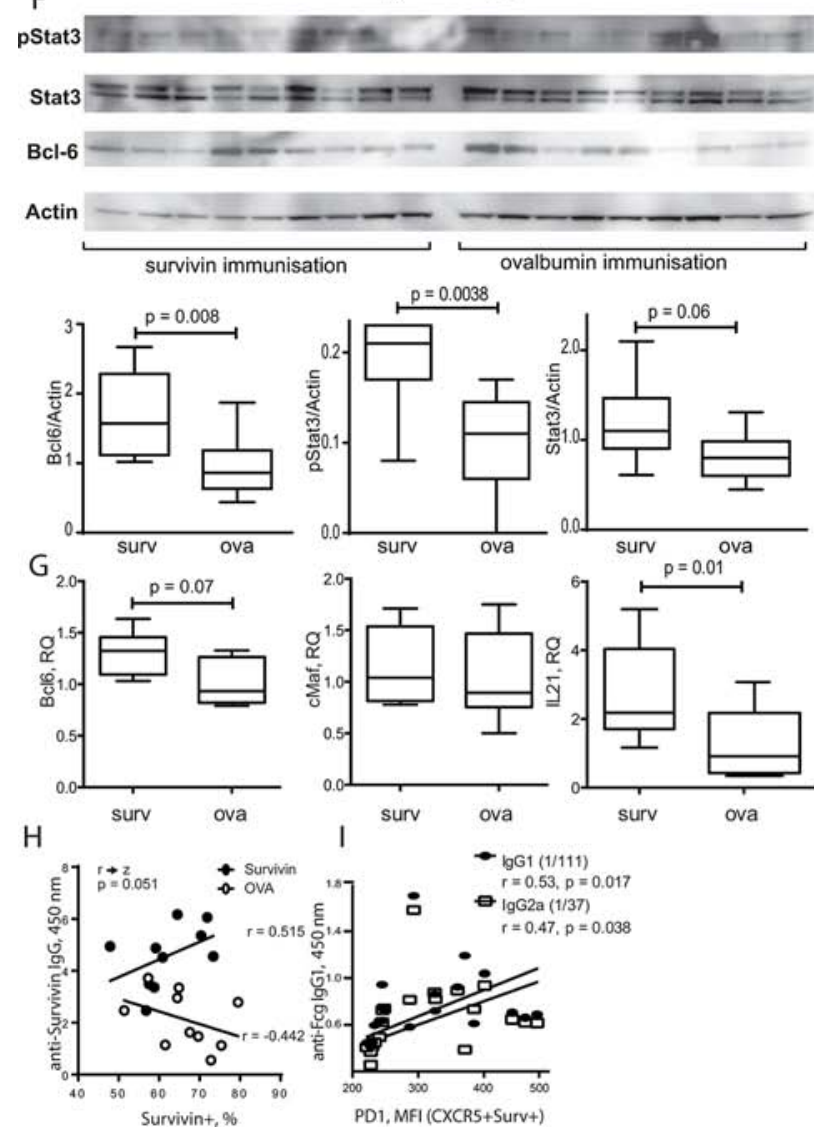

valbumin immunisation
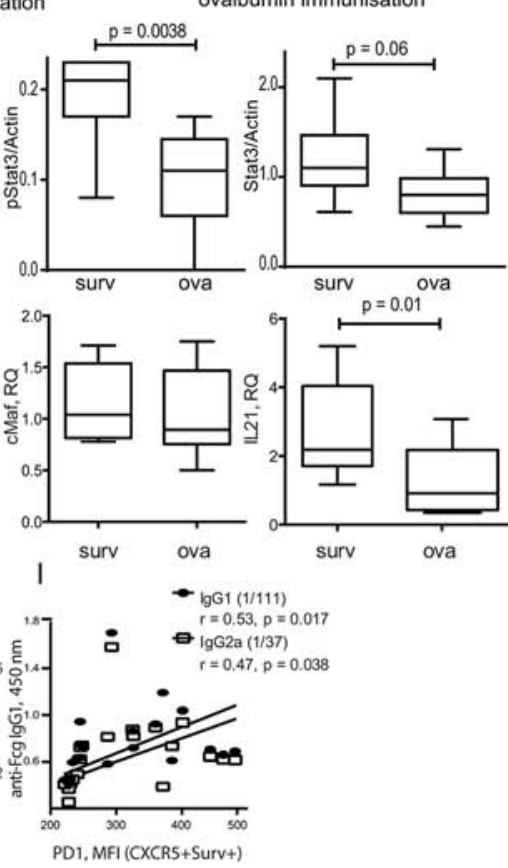

Figure 5: Exposure to survivin enriched PD-1 ${ }^{+}$Bcl-6 $^{+}$subset of Tfh cells via STAT3 dependent mechanisms. DBA/1 mice were immunized with survivin-derived peptide $(100 \mu \mathrm{g} /$ mouse $\times 4$, subcutaneously). Control mice were immunized with ovalbuminderived peptide (OVA). Both groups were then subjected to collagen-induced arthritis. Anti-survivin IgG antibodies, anti-Fcg antibodies, and survivin levels in serum were measured by ELISA A. Flow cytometry analysis of the expression of survivin B. in CD44h $\mathrm{CD} 4^{+}$lymphocytes, and expression of PD-1 C. and Bcl-6 E. in survivin ${ }^{+} \mathrm{CXCR} 5^{+} \mathrm{CD} 4^{+}$lymphocytes in spleen (SPL) and lymph nodes (LN). PD-1 expression correlated to the size of $\mathrm{CXCR}^{+}$survivin $^{+}$population $\mathbf{D}$. Dots represent individual mice and the horizontal line shows median of the group. Protein levels of active STAT3 phosphorylated at Y705 (pStat3), total Stat3, Bcl-6 and actin in spleen were analyzed by the Western blot F. The levels of each protein were quantified in ratio to actin of each sample. Quantification of the detected bands is presented as box plots. Transcription of Bcl-6, cMaf and IL-21 in the spleen was analyzed by RT-PCR and presented in relative quantity (RQ) to the median of the control group G. Anti-survivin antibodies in serum correlated with the size of survivin ${ }^{+} \mathrm{CD} 4$ population in spleen of survivin-immunized mice $\mathbf{H}$. Comparison of the correlations in the survivin- and OVA-immunized groups is done by the Fisher r-to-z transformation analysis. Anti-Fcg antibodies correlated with the intensity of PD-1 on the CXCR5 ${ }^{+}$survivin $^{+}$CD4 lymphocytes I., as measured by flow cytometry. Box plots with line represent IQR of the group and median, respectively, and error lines indicate min and max values. The Mann-Whitney $U$-test was used to compare differences between groups. Correlation analyses were performed using Spearman's test. 
cells (not shown) of the survivin-immunized mice was similar with the controls. Survivin-immunized mice had significantly increased population of PD- $1^{+}$(Figure 5C) and $\mathrm{Bcl}-6^{+}$cells (Figure $5 \mathrm{E}$ ) within survivin ${ }^{+} \mathrm{CXCR} 5^{+}$ CD4 cells in LN, suggesting enhanced maturation and activity of Tfh cells in the survivin-immunized mice. PD-1 expression on CD4 cells was in direct proportion to the size of survivin ${ }^{+} \mathrm{CXCR} 5^{+}$population $(r=0.73$, $p=0.0002$ ) (Figure 5D).

The survivin-immunized mice had higher production of Bcl-6 protein in spleen tissue compared to control OVA-immunized mice (Figure 5F). Transcriptional regulation of Bcl-6 relies on activation of transcription factor STAT3 [8]. The survivin immunized mice displayed a significant increase of the levels of total and Tyr705 phosphorylated STAT3 in western blot analysis of spleen cells (Figure 5F), which could be responsible for the increased transcription of Bcl-6 and IL-21 observed in the survivin-immunized mice (Figure 5G).

Consistent with the increased activity of Tfh cells, survivin-immunized mice had significantly increased level of anti-survivin antibodies (Figure 5A), which was also correlated with Bcl- $6^{+}$Survivin ${ }^{+} \mathrm{CXCR}^{+}$subset of CD4 cells $(r=0.44, p=0.05)$. Notably, the levels of antisurvivin antibodies appeared to be in direct dependence of the survivin ${ }^{+}$CD4 subset, and this reliance was not present in the OVA-immunized controls (Figure $5 \mathrm{H}$ ). The production of anti-Fc-gamma autoantibodies was readily detected in survivin-immunized mice (Figure 5B). The intensity of PD-1 expression on survivin ${ }^{+} \mathrm{CXCR}^{+} \mathrm{CD} 4$ cells was in direct proportion to the level of anti-Fc-gamma antibodies (Figure 5I).

\section{DISCUSSION}

This study demonstrates that intracellular expression of the oncoprotein survivin is a characteristic feature of Tfh cells in RA patients and in arthritic mice. The survivin positive subset of memory CD4 T cells possessed a complete signature of mature Tfh cells expressing CXCR5 and $\mathrm{PD}-1$ receptors and master transcription factor Bcl-6 required for Tfh function $[1,22]$. We also show that survivin expression is essential for formation and function of Tfh cells. Human survivin ${ }^{+}$ CD4 cells stimulated with IL-12 adopt Tfh phenotype in vitro as evidenced by the increased expression of CXCR5 on survivin ${ }^{+}$CD 4 cells. This $\mathrm{CXCR}^{+}$survivin $^{+}$ subset is shown responsible for the increased IL-21 production. This link between IL-12 and survivindependent maturation of $\mathrm{Tfh}$ cells deserves attention due to its replication in pre-symptomatic RA individuals where a strong association of serum survivin with IL-12 is found [48].

Taking advantage of the experimental arthritis model, we demonstrated that inhibition of survivin resulted in reduction of $\mathrm{Tfh}$ cells in the shSurv treated mice. This occurs through a limitation of the surface expression of CXCR5, which controls trafficking of Tfh cells into follicles and communication with B cells $[64,65]$. This limitation of CXCR5 expression on Tfh cells was clinically significant since it was associated with a decreased production of pathogenic anti-CII antibodies and confirmed the key role of survivin for Tfh maturation and function. In consistence with the pathogenic part of anti-CII antibodies in arthritis, the reduction of survivin expression delayed arthritis development and alleviated its severity [47].

Expression of CXCR5 is governed by the transcriptional repressor Bcl-6. Overexpression of Bcl-6 enhances CXCR5 and PD-1 through a micro-RNA dependent mechanism [66], while Bcl-6 deficient mice obtained by germline deletion [6] or by selective conditional approach in CD4 cells [67] had a reduced number and higher rate of apoptosis in $\mathrm{CXCR}^{+}$ PD- $1^{\text {hi }}$ Tfh cells. Transcription of Bcl- 6 was not inhibited by survivin deficiency, and shSurv treated mice had an increase of Bcl-6 mRNA. Notably, survivin inhibition had no effect on the transcriptional regulators of Th1, Th2 and Treg lineages, which is in line with a distinct place of survivin in maturation of Tfh cells. Bcl-6 is known to repress activity of the genes controlling genomic stability $[49,68]$. It protects malignant and damaged cells from apoptosis enabling cell cycle and may sustain proliferation of autoreactive T and B cell clones. Bcl-6 activity may predispose to aberrant immunity and permit production of autoantibodies. Rheumatoid factor, anti-Fc-gamma antibodies, belongs to the canonical autoantibody repertoire in RA. Production of these autoantibodies is detected in the experimental arthritis studied herein. Consistent with Bcl-6 dysfunction, the inhibition of survivin significantly diminished autoantibody production.

Bcl-6 is known to repress transcription of the Blimp-1 gene [7]. A release of Blimp-1 expression together with limited production of CXCR5 in shSurv treated mice exemplified insufficient function of Bcl-6 under survivin-deficient conditions. This resulted in ascending Blimp-1 control of lymphocyte maturation through inhibition of IL-2 and promoting memory CD8 T cells [47]. Imaging analysis of human CD4 cells shows co-localization of survivin with Bcl-6 within the nuclei of activated $\mathrm{CXCR}^{+}$cells. Its co-precipitation with the $\mathrm{BRE}$ in the promoter region of the Blimp-1 gene further supports functional synergy between survivin and Bcl-6. Our findings are in line with recent reports on the ability of survivin to bind chromatin $[69,70]$, and to regulate transcriptional activity of target genes [71]. The proposed structural model illustrates potential interaction between the BIR domain of survivin and the BTB domain of Bcl-6, and predicts survivin monomers to cross-link the Bcl-6 BTB dimers resulting in the oligomerization and activation of Bcl-6. This hypothetic model of survivin binding resembles those described for histone $\mathrm{H} 3$ and 
Smac/DIABLO $[72,73]$ and requires further prove in experimental structural studies.

Immunization experiments using survivin-derived peptides demonstrates that exposure of $\mathrm{Tfh}$ cell to extracellular survivin, clinically present in a substantial part of RA patients [63], serves as external regulator of Tfh cells. Survivin immunization induced no significant enlargement of Tfh subset, where the partiality of $\mathrm{CXCR}^{+}$Survivin $^{+}$ cells was similar to controls. It rather enhanced expression of PD- 1 and Bcl- 6 on the existing CXCR $5^{+}$survivin $^{+}$Tfh cells in $\mathrm{LN}$ restraining their activity. We show that the survivin immunized mice have increased production and activation of STAT3, which mediates pleiotropic cytokine signaling in RA [74]. In the Tfh cells of the survivin immunized mice, STAT3 activation together with the increased transcription of IL-21 results in the accumulation of $\mathrm{PD}-1^{+} \mathrm{Bcl}-6^{+}$ phenotype. [75, 76]Additionally, activation of STAT3 provides a positive feedback loop of survivin production by direct binding and activation of the survivin gene [77].

Taken together, the present study adds information on the phenotype and functional characteristics of Tfh cells in autoimmunity. We show that onco-protein survivin is required to induce and to maintain Tfh cell development and function. Survivin controls the CXCR5 expression and IL-21 production by CD4 lymphocytes coordinating activity of Bcl-6, the key regulator of Tfh maturation. Inhibition of survivin reduced formation of Tfh cells and autoantibody production. Extracellular exposure to survivin enhances Bcl-6 and PD-1 expression on Tfh cells in STAT3-dependent manner. These findings highlight the important role of the survivin-Bcl-6 axis in the pathogenesis of RA and provide a new link between transcriptional regulation of $\mathrm{T}$ cells and autoimmunity.

\section{MATERIALS AND METHODS}

\section{Patients and sample collection}

Peripheral blood (PB) samples were collected from 21 patients with established RA, diagnosed according to the ACR 1987 criteria [78]. All patients were recruited from the Rheumatology Clinic at the Sahlgrenska University Hospital, Gothenburg, Sweden, during the period from January 2014 to September 2014, and all patients gave written informed consent to the study. Clinical and demographic characteristics of the patients and their immunosuppressive treatment are presented in Table 1. The study is approved by the Regional Ethics Board in Gothenburg, Sweden (Dnr 633-07).

\section{Collagen-induced arthritis}

H-2q restricted DBA/1 mice (8 weeks old, male, Taconic Europe A/S, Ry, Denmark) were immunized with collagen type II (CII, $100 \mathrm{mg} /$ mouse) emulsified in an equal volume of complete (day 0 , intradermally) and incomplete (day 21, subcutaneously) Freund's adjuvant (Sigma-Aldrich, St. Louis, MO, USA) as described $[79,80]$. Disease progression was followed by assessment of weight and signs of arthritis in the individual mice. Samples of serum, bone marrow, spleen, draining lymph nodes and joints were collected for further analysis. All mice were housed at the animal facility at the Department of Rheumatology \& Inflammation Research, under standard conditions of temperature and light, and fed laboratory chow and water ad libitum. The experimental setting is approved by the animal ethics committee at the University of Gothenburg (permits 319-2011 and 272-2010).

\section{Inhibition of survivin in vivo}

Lentiviral construct, MISSION ${ }^{\circledR}$ TRCN0000054613 (shSurv13) and TRCN0000054616 (shSurv16) (Sigma-Aldrich), encoding small hairpin(sh)RNA targeting survivin, were used. Both shRNA target all three known isoforms of mouse survivin. The nontargeting shRNA controls (shNT) were subjected to MISSION $^{\circledR} \quad$ pLKO.1-puro non-mammalian shRNA control transduction particles (SHC002H) (SigmaAldrich). The constructs were given by a single intraperitoneal injection $\left(2-6 \times 10^{6}\right.$ transduction particles in $100 \mu \mathrm{l} /$ mouse) at the signs of clinical arthritis. Experiments were terminated 12 days after the injection of constructs. The toxicity of shRNA lentiviral particles has been investigated earlier [47].

\section{Immunization with survivin-derived peptides}

DBA/1 mice were immunized with a 15 aa survivin peptide (SVN53-67/M57-KLH) predicted to bind MHC class I and MHC class II alleles [81]. Control group was immunized with 15 aa ovalbumin peptide (OVA-KLH). The $100 \mu \mathrm{g}$ of peptides were emulsified with the incomplete Freund's adjuvant and delivered subcutaneously once weekly on 4 occasions, beginning 10 weeks ahead of the immunization with collagen II.

\section{Cell isolation and stimulation}

PBMC were isolated by density gradient separation on Lymphoprep (Axis-Shield PoC As, Norway). Cells were washed with PBS and cultured $1 \times 10^{6} / \mathrm{ml}$ in RPMI medium (RPMI1640, Gibco) supplemented with 5\% FCS, 2 mM Glutamax-1 (Gibco), $50 \mu \mathrm{M} \beta_{2}$-mercaptoethanol and $50 \mu \mathrm{g} / \mathrm{ml}$ gentamicin (Sanofi). To facilitate formation of Tfh cells, PBMC were activated with anti-CD3 antibodies $(0.25 \mu \mathrm{g} / \mathrm{ml}, \mathrm{SAB} 4700041$, Sigma-Aldrich) alone or in combination with IL-12 (20 ng/ml, BioSite, Sweden) and IL-21 (50 ng/ml, BioSite) for 5 days. GolgiPlug(555029, BD Biosciences) was added for the last $12 \mathrm{~h}$ of incubation to enable intracellular enrichment of IL-21. 
For imaging flow cytometry, CD4 T cells were isolated using positive magnetic beads separation followed by the bead detachment process as described $\left(\mathrm{CD}^{+}\right.$isolation kit, InVitrogen). The isolated CD4 cells were stimulated with Concanavalin A ( $5 \mu \mathrm{g} / \mathrm{ml}$, Sigma-Aldrich) for $3 \mathrm{~h}$.

Bone marrow cells from femur and tibia of arthritic mice were flushed with PBS. Spleens and lymph nodes were mashed through a $70 \mu \mathrm{m}$ cell strainer. Erythrocytes were lysed in $\mathrm{NH}_{4} \mathrm{Cl}$ solution $(0.83 \%, \mathrm{pH} 7.29)$, and cell pellets were washed with PBS and re-suspended in FACS buffer (PBS, 10\% FBS, 0.09\% NaN3, 0.5 mM EDTA). Cells for RNA preparation were lysed in RLT buffer (Qiagen, Valencia, CA, USA). Cells for western blot were lysed and sonicated in lysis buffer containing protease and phosphatase inhibitors (Complete Mini and PhosSTOP; Roche Diagnostics GmbH, Basel, Switzerland).

\section{Flow cytometry}

Single cell suspensions in FACS buffer (PBS, 10\% FBS, 0.09\% NaN3, 0.5 mM EDTA) were pre-incubated with Fc-block (BD Bioscience) as described [82]. For staining of human cells following antibodies were used: Anti-CD4 (SK3), anti-CXCR5 (RF8B2), anti-PD-1 (EH12.1) and anti-IL-21 (3A3-N2.1), purchased from BD Biosciences; anti-CD19 (H1B19), anti-CD45RA (HI100), from BioLegend. For staining of mouse cells the following antibodies were used: anti-CD4 (RM4-5, BD Biosciences); CD44 (IM7), anti-CXCR5 (SPRCL5), anti-PD-1 (RMPI-30) and CD62L (MEL-14) from eBioscience. Intracellular staining for Bcl-6, survivin and IL-21 was performed as previously described and according to the manufacturer's protocol [37]. Anti-Survivin (91630) and isotype control

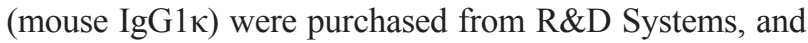
anti-Bcl-6 (K112-91), isotype control (mouse IgG1 $\kappa$, MOPC-21) were purchased from BD Biosciences and used for both human and mouse cells.

Stained cells were collected $\left(5 \times 10^{5}\right.$ events/ sample) by a FACSCanto II with FACSDiva software (BD Biosciences), and data evaluated using the FlowJo software (version 10.0.6, Tree Star Inc., Ashland, OR). Compensation for fluorochrome interferences was done using single stained CompBeads (BD Bioscience). Gating of the cells was based on the isotype control or on the fluorochrome minus one setting. Data is shown as percentage or mean fluorescence intensity (MFI), calculated in FlowJo and compared to data acquired in the same run.

\section{Imaging flow cytometry}

Cells were stained with FITC-conjugated antiCXCR5, PE-conjugated anti-survivin, and Alexa Fluor 647-conjugated anti-Bcl-6 antibodies, with the addition of DAPI $(3 \mu \mathrm{M})$ to visualize cell nuclei. Samples $\left(1 \times 10^{5}\right.$ cells $)$ were acquired on an imaging flow cytometer (ImageStreamX MkII, Amnis), and analysed using IDEAS v. 6.1 software (Amnis). Briefly, following colour compensation, focused, single cells were gated. Co-expression of CXCR5, survivin and Bcl- 6 was then analysed in this population using the intensity feature in IDEAS.

\section{Gene expression analysis}

Total RNA from splenocytes was extracted using an RNeasy Mini Kit (Qiagen, Valencia, CA). The concentration and quality of the RNA were evaluated with a NanoDrop spectrophotometer (Thermo Scientific, USA) and Experion (Bio-Rad laboratories Inc., USA). Real-time amplification was performed with $\mathrm{RT}^{2} \mathrm{SYBR}^{\circledR}$ Green qPCR Mastermix (Qiagen) using a ViiA TM 7 Real-Time PCR System (Applied Biosystems) as previously described [83]. The level of mRNA for Bcl-6, IL-21, NFAT1 and NFAT2 [62], Stat5b, IRF4, cMaf and Blimp-1 was measured. Expression levels of these genes were normalised to those of two reference genes, Gapdh and Ppia (TATAA Biocenter, Sweden). The sequences of primers used in the real-time PCR reaction are available upon request. The results were expressed as the fold change compared with the expression levels in the control cells with the ddCq-method.

\section{Protein preparation and western blotting}

Protein concentrations in cell lysates were measured by use of the Bicinchoninic Acid Protein Assay kit (Pierce, Rockford, IL, USA), according to the manufacturer's protocol. Proteins were separated on SDS-PAGE, 4-12\% Bis-Tris gels (NuPAGE; Invitrogen), and transferred to polyvinylidene difluoride membranes (NuPAGE; Invitrogen), which were blocked with 5\% BSA and incubated with anti-pStat3-Y705 (ab76315; Abcam, Cambridge, United Kingdom), anti-Stat3 (\#4904; Cell Signaling, Danvers, MA), anti-Bcl-6 (sc858; Santa Cruz Biotechnology, Santa Cruz, CA), or rabbit antiactin antibodies (A2066; Sigma-Aldrich) at $4^{\circ} \mathrm{C}$ overnight. Detection was performed with peroxidase-conjugated anti-rabbit secondary antibody (NA934VS; GE Healthcare Life Sciences, Pittsburgh, PA, USA) and Amersham ECL Select substrate (GE Healthcare Life Sciences). Chemiluminescent signals were visualized and quantified by the ChemiDoc equipment and Quantity One software (Bio-Rad Laboratories, Hercules, CA, USA).

\section{Autoantibody measurements}

Antigen specific antibodies to collagen type II, and antibodies to Fc-gamma (RF) were measured in serum using ELISA as described previously [80, 84]. Measurements were performed using a serial dilution of serum $\left(1: 10^{2}-1: 10^{7}\right)$ and results are expressed as the absorption at $450 \mathrm{~nm}$. 


\section{Chromatin immunoprecipitation (ChIP) analysis}

Human PBMC were isolated by density gradient separation on Lymphoprep (Axis-Shield PoC As, Norway), and cultured in the presence of Concanavalin $\mathrm{A}(0.625 \mu \mathrm{g} / \mathrm{ml}$, Sigma-Aldrich) and LPS (5 $\mu \mathrm{g} / \mathrm{ml}$, Sigma-Aldrich) for $72 \mathrm{~h}$. Cells were then cross-linked and lysed according to EpiTect ChIP OneDay kit (Qiagen). After sonication to shear the chromatin, cellular debris was removed by pelleting. After pre-clearing the chromatin, $1 \%$ of the sample was removed as "input fraction". The rest of the sample was incubated with either $2 \mu \mathrm{g}$ anti-Bcl-6 [85, 86] (N3, Santa Cruz Biotechnology), or anti-Survivin [87] (10811, Santa Cruz Biotechnology). In each experiment, one sample with unspecific antibody was included as negative control for nonspecific binding. A known Bcl-6-targeted sequence within the first non-coding exon of the $B c l-6$ gene was amplified and used as an internal positive control. The immune complexes were washed, the cross-links reversed and the DNA purified according to the EpiTect ChIP OneDay kit (Qiagen). The purified DNA was used as template in realtime amplification using different oligonucleotide pairs for p53 [52], Bcl-6 [86] and Blimp-1 [50]. PCR products were resolved on $2 \%$ agarose gels and visualized by ethidium bromide staining and quantified by the ChemiDoc equipment and Quantity One software (Bio-Rad Laboratories).

\section{Statistical analysis}

The median and interquartile range (IQR) for each group was calculated. Comparisons were done by the Mann-Whitney $U$-test or by the Wilcoxon matched-pairs signed rank test. A probability of 0.05 ( 2 tailed) was used as a significance threshold. Correlation analyses were performed using Spearman's test. Standard software GraphPad Prism (version 6.0 for Mac; GraphPad Software, San Diego, CA, USA) was used for statistical analyses.

\section{CONFLICTS OF INTEREST}

The authors declare no conflict of interest.

\section{GRANT SUPPORT}

This work has been supported by grants from the Swedish Research Council (grant number 521-2014-2637, to MBo); the Medical Society of Göteborg (MBo); the Swedish Association against Rheumatism (MBo); the King Gustaf V:s 80-year Foundation (MBo); the Commission of European Union (grant number FP7-Health 261460); Professor Nanna Swartz Foundation (MiB), Torsten Söderberg's Foundation (MBo); the Swedish Foundation for Strategic Research; the Ingabritt and Arne Lundberg's Foundation (MBo); the pharmacist Hedberg's Foundation (MiB); the University of Göteborg; and the Regional agreement on medical training and clinical research between the Western Götaland county council and the University of Göteborg (grant number LUA/ALF431141, to MBo). MBo holds the Medical Society of Göteborg Chair in Rheumatology (Sisters Högbergs minne). The funding sources have no involvement in study design; in the collection, analysis and interpretation of data; in the writing of the report; and in the decision to submit the article for publication.

\section{REFERENCES}

1. Nutt SL, Tarlinton DM. Germinal center B and follicular helper T cells: siblings, cousins or just good friends? Nat Immunol. 2011; 12:472-7.

2. Ma CS, Deenick EK. Human T follicular helper (Tfh) cells and disease. Immunol Cell Biol. 2014; 92:64-71.

3. Tangye SG, Cook MC, Fulcher DA. Insights into the role of STAT3 in human lymphocyte differentiation as revealed by the hyper-IgE syndrome. J Immunol. 2009; 182:21-8.

4. Crotty S. Follicular helper CD4 T cells (TFH). Annu Rev Immunol. 2011; 29621-63.

5. Linterman MA, Beaton L, Yu D, Ramiscal RR, Srivastava M, Hogan JJ, Verma NK, Smyth MJ, Rigby RJ, Vinuesa CG. IL-21 acts directly on B cells to regulate Bcl-6 expression and germinal center responses. J Exp Med. 2010; 207:353-63.

6. Nurieva RI, Chung Y, Martinez GJ, Yang XO, Tanaka S, Matskevitch TD, Wang YH, Dong C. Bcl6 mediates the development of T follicular helper cells. Science. 2009; 325:1001-5.

7. Johnston RJ, Poholek AC, DiToro D, Yusuf I, Eto D, Barnett B, Dent AL, Craft J, Crotty S. Bcl6 and Blimp-1 Are Reciprocal and Antagonistic Regulators of $\mathrm{T}$ Follicular Helper Cell Differentiation. Science. 2009; 325:1006-1010.

8. Liu X, Nurieva RI, Dong C. Transcriptional regulation of follicular T-helper (Tfh) cells. Immunol Rev. 2013; 252:139-45.

9. Ma CS, Avery DT, Chan A, Batten M, Bustamante J, Boisson-Dupuis S, Arkwright PD, Kreins AY, Averbuch D, Engelhard D, Magdorf K, Kilic SS, Minegishi Y, Nonoyama S, French MA, et al. Functional STAT3 deficiency compromises the generation of human $\mathrm{T}$ follicular helper cells. Blood. 2012; 119:3997-4008.

10. Holmdahl R, Malmstrom V, Burkhardt H. Autoimmune priming, tissue attack and chronic inflammation - the three stages of rheumatoid arthritis. Eur J Immunol. 2014; 44:1593-9.

11. Scott DL, Wolfe F, Huizinga TWJ. Rheumatoid arthritis. The Lancet. 2010; 376:1094-1108.

12. Weyand CM, Goronzy JJ. Ectopic Germinal Center Formation in Rheumatoid Synovitis. Annals of the New York Academy of Sciences. 2003; 987:140-149. 
13. Vinuesa CG, Sanz I, Cook MC. Dysregulation of germinal centres in autoimmune disease. Nat Rev Immunol. 2009; 9:845-57.

14. Amara K, Steen J, Murray F, Morbach H, Fernandez-Rodriguez BM, Joshua V, Engstrom M, Snir O, Israelsson L, Catrina AI, Wardemann H, Corti D, Meffre E, Klareskog L, Malmstrom V. Monoclonal IgG antibodies generated from joint-derived B cells of RA patients have a strong bias toward citrullinated autoantigen recognition. J Exp Med. 2013; 210:445-55.

15. Bukhari M, Thomson W, Naseem H, Bunn D, Silman A, Symmons D, Barton A. The performance of anti-cyclic citrullinated peptide antibodies in predicting the severity of radiologic damage in inflammatory polyarthritis: results from the Norfolk Arthritis Register. Arthritis Rheum. 2007; 56:2929-35.

16. Forslind K, Ahlmen M, Eberhardt K, Hafstrom I, Svensson B. Prediction of radiological outcome in early rheumatoid arthritis in clinical practice: role of antibodies to citrullinated peptides (anti-CCP). Ann Rheum Dis. 2004; 63:1090-5.

17. Kastbom A, Strandberg G, Lindroos A, Skogh T. Anti-CCP antibody test predicts the disease course during 3 years in early rheumatoid arthritis (the Swedish TIRA project). Ann Rheum Dis. 2004; 63:1085-9.

18. Meyer O, Labarre C, Dougados M, Goupille P, Cantagrel A, Dubois A, Nicaise-Roland P, Sibilia J, Combe B. Anticitrullinated protein/peptide antibody assays in early rheumatoid arthritis for predicting five year radiographic damage. Ann Rheum Dis. 2003; 62:120-6.

19. Chevalier N, Jarrossay D, Ho E, Avery DT, Ma CS, Yu D, Sallusto F, Tangye SG, Mackay CR. CXCR5 expressing human central memory CD4 T cells and their relevance for humoral immune responses. J Immunol. 2011; 186:5556-68.

20. Morita R, Schmitt N, Bentebibel SE, Ranganathan R, Bourdery L, Zurawski G, Foucat E, Dullaers M, Oh S, Sabzghabaei N, Lavecchio EM, Punaro M, Pascual V, Banchereau J, Ueno H. Human blood CXCR5(+)CD4(+) $\mathrm{T}$ cells are counterparts of $\mathrm{T}$ follicular cells and contain specific subsets that differentially support antibody secretion. Immunity. 2011; 34:108-21.

21. He J, Tsai LM, Leong YA, Hu X, Ma CS, Chevalier N, Sun X, Vandenberg K, Rockman S, Ding Y, Zhu L, Wei W, Wang C, Karnowski A, Belz GT, et al. Circulating precursor CCR7(lo)PD-1(hi) CXCR5(+) CD4(+) T cells indicate Tfh cell activity and promote antibody responses upon antigen reexposure. Immunity. 2013; 39:770-81.

22. Tangye SG, Ma CS, Brink R, Deenick EK. The good, the bad and the ugly - TFH cells in human health and disease. Nat Rev Immunol. 2013; 13:412-26.

23. Liu R, Wu Q, Su D, Che N, Chen H, Geng L, Chen J, Chen W, Li X, Sun L. A regulatory effect of IL-21 on T follicular helper-like cell and B cell in rheumatoid arthritis. Arthritis Res Ther. 2012; 14:R255.
24. Ma J, Zhu C, Ma B, Tian J, Baidoo SE, Mao C, Wu W, Chen J, Tong J, Yang M, Jiao Z, Xu H, Lu L, Wang S. Increased frequency of circulating follicular helper $\mathrm{T}$ cells in patients with rheumatoid arthritis. Clin Dev Immunol. 2012; 2012:827480.

25. Wang J, Shan Y, Jiang Z, Feng J, Li C, Ma L, Jiang Y. High frequencies of activated $\mathrm{B}$ cells and $\mathrm{T}$ follicular helper cells are correlated with disease activity in patients with new-onset rheumatoid arthritis. Clin Exp Immunol. 2013; 174:212-20.

26. Rasmussen TK, Andersen T, Hvid M, Hetland ML, Horslev-Petersen K, Stengaard-Pedersen K, Holm CK, Deleuran B. Increased interleukin 21 (IL-21) and IL-23 are associated with increased disease activity and with radiographic status in patients with early rheumatoid arthritis. J Rheumatol. 2010; 37:2014-20.

27. Andersson KM, Cavallini NF, Hu D, Brisslert M, Cialic R, Valadi H, Erlandsson MC, Silfversward S, Pullerits R, Kuchroo VK, Weiner HL, Bokarewa MI. Pathogenic transdifferentiation of Th17 cells contribute to perpetuation of rheumatoid arthritis during anti-TNF treatment. Mol Med. 2015; doi:10.2119/molmed 2015.00057.

28. Arroyo-Villa I, Bautista-Caro MB, Balsa A, AguadoAcin $\mathrm{P}$, Bonilla-Hernan MG, Plasencia C, Villalba A, Nuno L, Puig-Kroger A, Martin-Mola E, Miranda-Carus ME. Constitutively altered frequencies of circulating follicullar helper $\mathrm{T}$ cell counterparts and their subsets in rheumatoid arthritis. Arthritis Res Ther. 2014; 16:500.

29. Pratt AG, Swan DC, Richardson S, Wilson G, Hilkens CM, Young DA, Isaacs JD. A CD4 T cell gene signature for early rheumatoid arthritis implicates interleukin 6-mediated STAT3 signalling, particularly in anti-citrullinated peptide antibody-negative disease. Ann Rheum Dis. 2012; 71:1374-81.

30. Isomaki $\mathrm{P}$, Junttila I, Vidqvist $\mathrm{KL}$, Korpela $\mathrm{M}$, Silvennoinen O. The activity of JAK-STAT pathways in rheumatoid arthritis: constitutive activation of STAT3 correlates with interleukin 6 levels. Rheumatology (Oxford). 2015; 54:1103-13.

31. Boyle DL, Soma K, Hodge J, Kavanaugh A, Mandel D, Mease P, Shurmur R, Singhal AK, Wei N, Rosengren S, Kaplan I, Krishnaswami S, Luo Z, Bradley J, Firestein GS. The JAK inhibitor tofacitinib suppresses synovial JAK1-STAT signalling in rheumatoid arthritis. Ann Rheum Dis. 2015; 74:1311-6.

32. Anderson AE, Pratt AG, Sedhom MA, Doran JP, Routledge C, Hargreaves B, Brown PM, Le Cao KA, Isaacs JD, Thomas R. IL-6-driven STAT signalling in circulating CD4+ lymphocytes is a marker for early anticitrullinated peptide antibody-negative rheumatoid arthritis. Ann Rheum Dis. 2015; doi:10.1136/annrheumdis 2014-20585.

33. Ambrosini G, Adida C, Altieri DC. A novel anti-apoptosis gene, survivin, expressed in cancer and lymphoma. Nat Med. 1997; 3:917-21. 
34. Altieri DC. Survivin, cancer networks and pathway-directed drug discovery. Nat Rev Cancer. 2008; 8:61-70.

35. Okada H, Bakal C, Shahinian A, Elia A, Wakeham A, Suh WK, Duncan GS, Ciofani M, Rottapel R, Zuniga-Pflucker JC, Mak TW. Survivin loss in thymocytes triggers p53-mediated growth arrest and p53-independent cell death. J Exp Med. 2004; 199:399-410.

36. Xing Z, Conway EM, Kang C, Winoto A. Essential role of survivin, an inhibitor of apoptosis protein, in T cell development, maturation, and homeostasis. J Exp Med. 2004; 199:69-80.

37. Andersson SE, Svensson MN, Erlandsson MC, Dehlin M, Andersson KM, Bokarewa MI. Activation of Fms-like tyrosine kinase 3 signaling enhances survivin expression in a mouse model of rheumatoid arthritis. PLoS One. 2012; 7:e47668

38. Singh P, Hoggatt J, Hu P, Speth JM, Fukuda S, Breyer RM, Pelus LM. Blockade of prostaglandin E2 signaling through EP1 and EP3 receptors attenuates Flt3L-dependent dendritic cell development from hematopoietic progenitor cells. Blood. 2012; 119:1671-82.

39. Lei F, Song J, Haque R, Xiong X, Fang D, Wu Y, Lens SM, Croft M. Transgenic expression of survivin compensates for OX40-deficiency in driving Th2 development and allergic inflammation. Eur J Immunol. 2013; 43:1914-24.

40. Bokarewa M, Lindblad S, Bokarew D, Tarkowski A. Balance between survivin, a key member of the apoptosis inhibitor family, and its specific antibodies determines erosivity in rheumatoid arthritis. Arthritis Res Ther. 2005; 7:R349-58.

41. Chun-Lai T, Murad S, Erlandsson MC, Hussein H, Sulaiman W, Dhaliwal JS, Bokarewa MI. Recognizing rheumatoid arthritis: oncoprotein survivin opens new possibilities: a population-based case-control study. Medicine (Baltimore). 2015; 94:e468.

42. Isgren A, Forslind K, Erlandsson M, Axelsson C, Andersson S, Lund A, Bokarewa M. High survivin levels predict poor clinical response to infliximab treatment in patients with rheumatoid arthritis. Semin Arthritis Rheum. 2012; 41:652-7.

43. Svensson B, Hafstrom I, Erlandsson MC, Forslind K, Bokarewa MI. Smoking in combination with antibodies to cyclic citrullinated peptides is associated with persistently high levels of survivin in early rheumatoid arthritis: a prospective cohort study. Arthritis Res Ther. 2014; 16:R12.

44. Baran M, Mollers LN, Andersson S, Jonsson IM, Ekwall AK, Bjersing J, Tarkowski A, Bokarewa M. Survivin is an essential mediator of arthritis interacting with urokinase signalling. J Cell Mol Med. 2009; 13:3797-808.

45. Dharmapatni AA, Smith MD, Findlay DM, Holding CA, Evdokiou A, Ahern MJ, Weedon H, Chen P, Screaton G, Xu XN, Haynes DR. Elevated expression of caspase-3 inhibitors, survivin and XIAP correlates with low levels of apoptosis in active rheumatoid synovium. Arthritis Res Ther. 2009; 11:R13.

46. Smith MD, Weedon H, Papangelis V, Walker J, Roberts-Thomson PJ, Ahern MJ. Apoptosis in the rheumatoid arthritis synovial membrane: modulation by disease-modifying anti-rheumatic drug treatment. Rheumatology (Oxford). 2010; 49:862-75.

47. Andersson KM, Svensson MN, Erlandsson MC, Jonsson IM, Bokarewa MI. Down-regulation of survivin alleviates experimental arthritis. J Leukoc Biol. 2015; 97:135-45.

48. Bokarewa M, Brink M, Erlandsson M, Rantapaa Dahlqvist S. Survivin but not Fms-like tyrosine kinase 3 ligand is up-regulated before the onset of rheumatoid arthritis: a pilot study. Arthritis Res Ther. 2014; 16:R45.

49. Crotty S, Johnston RJ, Schoenberger SP. Effectors and memories: Bcl-6 and Blimp-1 in T and B lymphocyte differentiation. Nat Immunol. 2010; 11:114-20.

50. Tunyaplin C, Shaffer AL, Angelin-Duclos CD, Yu X, Staudt LM, Calame KL. Direct repression of prdm1 by Bcl-6 inhibits plasmacytic differentiation. J Immunol. 2004; 173:1158-65.

51. Parekh S, Polo JM, Shaknovich R, Juszczynski P, Lev P, Ranuncolo SM, Yin Y, Klein U, Cattoretti G, Favera RD, Shipp MA, Melnick A. BCL6 programs lymphoma cells for survival and differentiation through distinct biochemical mechanisms. Blood. 2007; 110:2067-2074.

52. Phan RT, Dalla-Favera R. The BCL6 proto-oncogene suppresses p53 expression in germinal-centre B cells. Nature. 2004; 432:635-9.

53. Margalit $\mathrm{O}$, Amram $\mathrm{H}$, Amariglio $\mathrm{N}$, Simon AJ, Shaklai S, Granot G, Minsky N, Shimoni A, Harmelin A, Givol D, Shohat M, Oren M, Rechavi G. BCL6 is regulated by $\mathrm{p} 53$ through a response element frequently disrupted in B-cell non-Hodgkin lymphoma. Blood. 2006; 107:1599-607.

54. Ghetu AF, Corcoran CM, Cerchietti L, Bardwell VJ, Melnick A, Prive GG. Structure of a BCOR corepressor peptide in complex with the BCL6 BTB domain dimer. Molecular cell. 2008; 29:384-91.

55. Ahmad KF, Melnick A, Lax S, Bouchard D, Liu J, Kiang CL, Mayer S, Takahashi S, Licht JD, Prive GG. Mechanism of SMRT corepressor recruitment by the BCL6 BTB domain. Molecular cell. 2003; 12:1551-64.

56. Chantalat L, Skoufias DA, Kleman JP, Jung B, Dideberg O, Margolis RL. Crystal structure of human survivin reveals a bow tie-shaped dimer with two unusual alpha-helical extensions. Molecular cell. 2000; 6:183-9.

57. Comeau SR, Gatchell DW, Vajda S, Camacho CJ. ClusPro: a fully automated algorithm for protein-protein docking. Nucleic acids research. 2004; 32:W96-9.

58. Kozakov D, Hall DR, Beglov D, Brenke R, Comeau SR, Shen Y, Li K, Zheng J, Vakili P, Paschalidis I, Vajda S. Achieving reliability and high accuracy in automated protein docking: ClusPro, PIPER, SDU, and stability analysis in CAPRI rounds 13-19. Proteins. 2010; 78:3124-30.

59. Janin J, Henrick K, Moult J, Eyck LT, Sternberg MJ, Vajda S, Vakser I, Wodak SJ. CAPRI: a Critical Assessment of PRedicted Interactions. Proteins. 2003; 52:2-9.

60. Vinuesa CG, Cyster JG. How T cells earn the follicular rite of passage. Immunity. 2011; 35:671-80. 
61. Ma CS, Deenick EK, Batten M, Tangye SG. The origins, function, and regulation of $\mathrm{T}$ follicular helper cells. J Exp Med. 2012; 209:1241-53.

62. Vaeth M, Muller G, Stauss D, Dietz L, Klein-Hessling S, Serfling E, Lipp M, Berberich I, Berberich-Siebelt F. Follicular regulatory $\mathrm{T}$ cells control humoral autoimmunity via NFAT2-regulated CXCR5 expression. J Exp Med. 2014; 211:545-61.

63. Svensson B, Hafstrom I, Forslind K, Albertsson K, Tarkowski A, Bokarewa M. Increased expression of protooncogene survivin predicts Joint destruction and persistent disease activity in early rheumatoid arthritis. Ann Med. 2010; 42:45-54.

64. Breitfeld D, Ohl L, Kremmer E, Ellwart J, Sallusto F, Lipp M, Forster R. Follicular B helper T cells express CXC chemokine receptor 5, localize to B cell follicles, and support immunoglobulin production. J Exp Med. 2000; 192:1545-52.

65. Schaerli P, Willimann K, Lang AB, Lipp M, Loetscher P, Moser B. CXC chemokine receptor 5 expression defines follicular homing $\mathrm{T}$ cells with B cell helper function. J Exp Med. 2000; 192:1553-62.

66. Yu D, Rao S, Tsai LM, Lee SK, He Y, Sutcliffe EL, Srivastava M, Linterman M, Zheng L, Simpson N, Ellyard JI, Parish IA, Ma CS, Li QJ, Parish CR, et al. The transcriptional repressor Bcl-6 directs $\mathrm{T}$ follicular helper cell lineage commitment. Immunity. 2009; 31:457-68.

67. Hollister K, Kusam S, Wu H, Clegg N, Mondal A, Sawant DV, Dent AL. Insights into the role of Bcl6 in follicular Th cells using a new conditional mutant mouse model. J Immunol. 2013; 191:3705-11.

68. Bunting KL, Melnick AM. New effector functions and regulatory mechanisms of BCL6 in normal and malignant lymphocytes. Curr Opin Immunol. 2013; 25:339-46.

69. Kelly AE, Ghenoiu C, Xue JZ, Zierhut C, Kimura H, Funabiki H. Survivin Reads Phosphorylated Histone H3 Threonine 3 to Activate the Mitotic Kinase Aurora B. Science. 2010; 330:235-239.

70. Yamagishi Y, Honda T, Tanno Y, Watanabe Y. Two histone marks establish the inner centromere and chromosome bi-orientation. Science. 2010; 330:239-43.

71. Wang H, Holloway MP, Ma L, Cooper ZA, Riolo M, Samkari A, Elenitoba-Johnson KS, Chin YE, Altura RA. Acetylation directs survivin nuclear localization to repress STAT3 oncogenic activity. J Biol Chem. 2010; 285:36129-37.

72. Du J, Kelly AE, Funabiki H, Patel DJ. Structural basis for recognition of H3T3ph and Smac/DIABLO N-terminal peptides by human Survivin. Structure. 2012; 20:185-95.

73. Jeyaprakash AA, Basquin C, Jayachandran U, Conti E. Structural basis for the recognition of phosphorylated histone $\mathrm{h} 3$ by the survivin subunit of the chromosomal passenger complex. Structure. 2011; 19:1625-34.

74. Choy E. Understanding the dynamics: pathways involved in the pathogenesis of rheumatoid arthritis. Rheumatology (Oxford). 2012; 51:v3-11.
75. Linterman MA, Vinuesa CG. Signals that influence $\mathrm{T}$ follicular helper cell differentiation and function. Semin Immunopathol. 2010; 32:183-96.

76. Choi YS, Yang JA, Crotty S. Dynamic regulation of Bcl6 in follicular helper CD4 T (Tfh) cells. Curr Opin Immunol. 2013; 25:366-72.

77. Gritsko T, Williams A, Turkson J, Kaneko S, Bowman T, Huang M, Nam S, Eweis I, Diaz N, Sullivan D, Yoder S, Enkemann S, Eschrich S, Lee JH, Beam CA, et al. Persistent activation of stat 3 signaling induces survivin gene expression and confers resistance to apoptosis in human breast cancer cells. Clin Cancer Res. 2006; 12:11-9.

78. Arnett FC, Edworthy SM, Bloch DA, McShane DJ, Fries JF, Cooper NS, Healey LA, Kaplan SR, Liang MH, Luthra HS, Medsger TA, Mitchell DM, Neustadt DH, Pinals RS, Schaller JG, et al. The American Rheumatism Association 1987 revised criteria for the classification of rheumatoid arthritis. Arthritis Rheum. 1988; 31:315-24.

79. Brand DD, Latham KA, Rosloniec EF. Collagen-induced arthritis. Nat Protoc. 2007; 2:1269-75.

80. Lindblad SS, Mydel P, Jonsson IM, Senior RM, Tarkowski A, Bokarewa M. Smoking and nicotine exposure delay development of collagen-induced arthritis in mice. Arthritis Res Ther. 2009; 11:R88.

81. Ciesielski MJ, Ahluwalia MS, Munich SA, Orton M, Barone T, Chanan-Khan A, Fenstermaker RA. Antitumor cytotoxic T-cell response induced by a survivin peptide mimic. Cancer Immunol Immunother. 2010; 59:1211-21.

82. Rehnberg M, Amu S, Tarkowski A, Bokarewa MI, Brisslert M. Short- and long-term effects of anti-CD20 treatment on B cell ontogeny in bone marrow of patients with rheumatoid arthritis. Arthritis Res Ther. 2009; 11:R123.

83. Svensson MN, Andersson SE, Erlandsson MC, Jonsson IM, Ekwall AK, Andersson KM, Nilsson A, Bian L, Brisslert M, Bokarewa MI. Fms-like tyrosine kinase 3 ligand controls formation of regulatory $\mathrm{T}$ cells in autoimmune arthritis. PLoS One. 2013; 8:e54884.

84. Dehlin $\mathrm{M}$, Andersson $\mathrm{S}$, Erlandsson $\mathrm{M}$, Brisslert $\mathrm{M}$, Bokarewa M. Inhibition of fms-like tyrosine kinase 3 alleviates experimental arthritis by reducing formation of dendritic cells and antigen presentation. J Leukoc Biol. 2011; 90:811-7.

85. Niu H, Cattoretti G, Dalla-Favera R. BCL6 controls the expression of the $\mathrm{B} 7-1 / \mathrm{CD} 80$ costimulatory receptor in germinal center B cells. J Exp Med. 2003; 198:211-21.

86. Pasqualucci L, Migliazza A, Basso K, Houldsworth J, Chaganti RS, Dalla-Favera R. Mutations of the BCL6 proto-oncogene disrupt its negative autoregulation in diffuse large B-cell lymphoma. Blood. 2003; 101:2914-23.

87. Tang L, Ling X, Liu W, Das GM, Li F. Transcriptional inhibition of $\mathrm{p} 21 \mathrm{WAF} 1 / \mathrm{CIP} 1$ gene (CDKN1) expression by survivin is at least partially p53-dependent: evidence for survivin acting as a transcription factor or co-factor. Biochem Biophys Res Commun. 2012; 421:249-54. 